\title{
Restriction of burial rites during the COVID-19 pandemic: An African liturgical and missional challenge
}

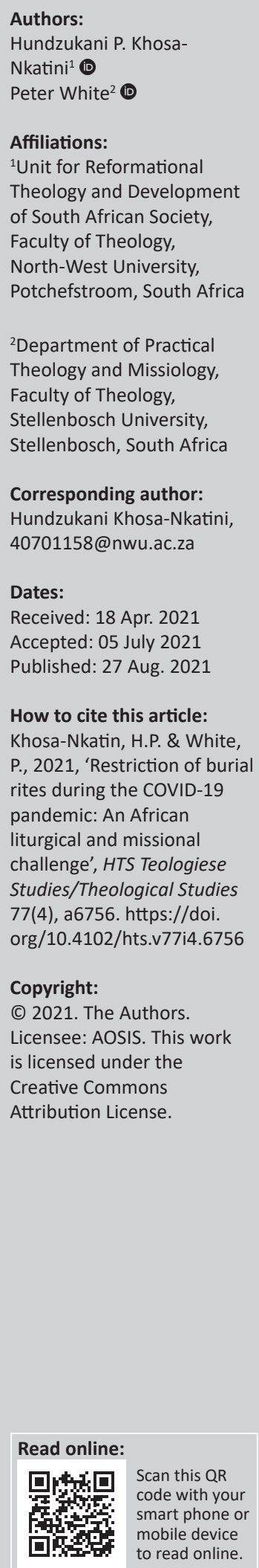

Burial rites are very common among many Africa communities. In the African context, burials are not the end of life but rather the beginning of another life in the land of the ancestors. In spite of the importance of the African funeral rites, the missional role of the church in mourning and the burial of the dead in the African communities, the COVID-19 pandemic led protocols and restrictions placed a huge challenge on the African religious and cultural practices.

Contribution: In the light of the above-named challenges, the article discusses the religiouscultural effect of the pandemic with special focus on the African liturgical and missiological challenges in the context of the COVID-19 restrictions on funerals and burial rites.

Keywords: lockdown; burial rites; African; pastoral practices; COVID-19; church; liturgy; funeral; mission.

\section{Introduction}

Burial rites are very common in many Africa communities. In the African context, burials are not the end of life but rather the beginning of another life in the land of the ancestors. During the early stages of the COVID-19 pandemic in South Africa, the president of the Republic of South Africa, President Cyril Ramaphosa, announced the beginning of lockdown in March 2020 as a response to the global pandemic. The lockdown came with many restrictions to counter the spread of the virus, and included restrictions on both religious and social gatherings. Unlike in the Western culture whereby mourning of the dead and funerals are seen as a private family matter, the African communities see it differently. In the African context, it is believed that funeral and bereavement rituals are meant to help purify the mourners. In view of this, in most part of Africa funerals, especially of an elder, is a major social event and is attended by a multitude of people. There are burial rites that takes place leading to the day of the funeral, some of these rituals requires the dead body to kept for days before the funeral. Further, in Christian communities, the church uses the funeral ceremonies for propagation of the missional agenda. However, lockdown restrictions made it impossible for such rituals to take place, especially if someone had passed away due to COVID-19 related illness. This has challenged the African burial rites and rituals, for most, if not all, the Africans communities.

Existing research on the COVID-19 pandemic was geared towards health, religious, economic, and political perspectives of the challenges posed by the pandemic on human existence. This article, in light of the above mentioned challenges, seeks to address the religious-cultural perspectives of the pandemic with special focus on the African liturgical and missiological challenges in the context of the restrictions on the burial rites.

The focus of the liturgical and missional approach in this article is limited to African burial rites and rituals in the context of the COVID-19 pandemic. The article also emphasises on the interdisciplinary discourse between the African culture, and the missional and liturgical concepts. The article employed literature study as the tool for data gathering, and the analysis is presented thematically.

\section{African spirituality in relation to the dead}

This section discusses the African pneumatic worldview in the context of the journey of the dead from the physical world to the world of spirits. Mbiti (1991) sees death:

$[A] \mathrm{s}$ one of the most universal and mysterious experiences in human life. Death is a thing standing between the world of human beings and the world of spirits and that onto logical departure of someone requires rituals that are intended at uniting the two worlds. (p. 3) 
One cannot speak of the African burial rites and rituals without speaking of the African spirituality. Funerals in the African context are considered to be a spiritual journey, not only for the dead but also the living. Magesa (1997) argues that:

$[D]$ ialogue between Christianity and African Religion has never been in the past a real conversation at any of these levels. On the contrary, contact between Christianity and African Religion has historically been predominantly a monologue, believed by assumptions prejudicial against the latter, with Christianity culturally more vocal and ideologically more aggressive. (p. 5)

Therefore, what has been greatly documented and spread to date is largely Christians speaking about African religions, and not Africans speaking for themselves.

Wesley and Kurewa (2000:24) submit that, it has been interesting to observe how other people who have had an interest in writing about African religion have had difficulties in trying to figure African beliefs. Mpedi (2008:106) argues that 'because the traditional religion of the African people has a strong cultural base, the various group have different rituals but there are certain common features'. This thus implies that the basic structure of culture is universal as every culture comprises main elements such as beliefs and values, norms, symbols and language (Hammersley \& Atkinson 2007:13; Mbiti 1975:195). These four elements of culture are passed from one generation to the next through socialisation, stories and games, poems, religious rituals, jokes, and other learning activities (Ntuli 2012:20).

In African cultural spirituality, 'the ancestors are not gods. In African indigenous context, they play a key part in bringing about either good or ill fortune' (Mpedi 2008:106). Therefore, maintaining good relations with the ancestors is vital and they have to be appeased regularly by a variety of ritual offering. Within this relationship, they are not worshiped, but venerated by individuals and the community.

According to Beyers (2010:6) the belief in ancestors is central to traditional African thought and is an essential pillar of their religious practice. In the African indigenous religion, the natural relationship between ancestors and the earthly descendants is usually that of parents and offspring. Children consider their parents and grandparents as direct ancestors. It is also believed that ancestors automatically acquire some kind of supernatural power or sacred status (Magesa 1997:51-53; White 2015:2). This belief is based on the African dynamistic and animistic worldview. In their view, the spirit of the ancestor is merely a personal power reigning over some 'holy domain or sacred places'.

\section{Mcveigh (1974) argues that:}

Africans conceive of God as far away and remote, and this conception has its influence on their worship life. In general, they do not go to God directly or make regular prayers to him. (p. 109)

In their view, the ancestors serve as mediators between God and man (Mcveigh 1974:115). Moreover, the ancestors are subject to the same emotions as the living members of the community, and their moods are not constant. Since they may be jealous or fickle, the living must be careful not to offend them (Mcveigh 1974):

If the ancestors are neglected, they most assuredly will be angry and will seek to demonstrate their feelings by some vindictive action. In such a case, offerings are made to placate the one offended. (p. 29)

The ancestors are more important than the tribal deities in the daily life of the Africans. They are nearer and more concerned with the fate of their own family members. The clan and tribal divinities are remote and are therefore uninterested in the mundane problems of man's daily existence. This statement also expresses accurately man's relationship with the Supreme God. Neither the tribal king nor God are to be bothered with petty problems of men. One only comes before such high entities with matters of great important, when all other avenues of action have failed. (pp. 34-35)

For Africans, ancestors need to be kept happy all the time, so that they bless those that are still alive. It is believed that they still take part in the daily routine of the family. Furthermore, ancestors are regarded as custodians and they are believed to know more than the living. They can bring good luck and bad luck equally if they are pleased or angered respectively (Edwards et al. 2009):

Ancestors are mostly acknowledged for up to four or five generations whereupon the memory of those ancestors dies out and they are considered to be truly dead. Exemplarity, ancestors are considered to be good models for human behavior. Their act of virtue is seen as good examples of proper life. Their way of life educates the living on proper social behaviour. (p. 7)

In light of the African spiritual orientation of death and the journey to the world of spirits after death, family members are required to (Mndende 2005):

$[P]$ erform a welcoming ceremony to help ease the passage of the dead person into the spirit world. In some communities, it is believed that the death of a member of the family also causes the family household to become unclean, and therefore requires ritual cleansing ceremonies. (p. 19)

Baloyi (2014:6) says that in the African context, death can be something that can 'take away' the whole family if a ritual is not performed following the death of a family member.

\section{The challenge of COVID-19 restrictions on funeral and burial}

Bassis, Celles and Levine (1991) posit that, in African communities:

During the period of bereavement neighbors and friends open their houses to the people who have come to pay their last respect. In most instance, a cordial relationship exists between people in the vicinity of the bereaved family. One has to be seen to care about other people's pain. Neighbors will spend days with the bereaved, taking care of their needs, cooking, welcoming mourners and even offering a place to sleep to those who have come far away. (p. 12) 
For centuries in Africa, rituals like night vigil and viewing of the body have been norm and are regarded as a dignified way to bid farewell to the loved ones. These practices were however not permitted under the COVID-19 protocol. Scientific observations of the spread of COVID-19 pandemic shows that burial rituals and funerals are considered to be among super spreader of the deadly coronavirus.

During lockdown level five, it was stipulated that only 50 people could attend a funeral. Wearing face mask, regular washing of hand with water and soap and sanitizing were the required COVID-19 protocols for public gatherings and funerals. However, these regulations and protocols were ignored by the members many African communities apropos of funerals. Furthermore, the President appealed that one should attend a funeral if and only, when necessary. In most African cultures, it is considered necessary for the whole village to attend the funeral of a dead community member. Therefore, enforcing these restrictions remained a challenge in the South African rural areas.

\section{African concept of family in the context of mourning the dead}

To appreciate the reason behind the African worldview of mourning the dead and performing burial rituals, it would be essential to first understand the concept of family. Family in African context is not just blood. It is not defined as the immediate family or the extended family. Family is family, terms such as 'cousin' are considered to be Western concepts. In the African context, your cousin is your sibling. There is no such thing as a 'niece' or a 'nephew', your siblings children are considered as your children. At the time of funeral, the local church, the burial society or simply a passer-by who heard about the bereavement and comes to support the family, are all considered as part of the family. Everyone present on the day and the venue of the funeral are there purposely to mourn with the family of the deceased, and to pay last respects. Africans can travel over $500 \mathrm{~km}$ to attend a funeral of their grandparents' neighbours. According to Baloyi (2014:2) your faithfulness is proven through your attendance at other people's funeral, the more likely it is that mourners will come to help you when a member of your own family dies. Large number of people coming together for a funeral from far away, is not only normal for Africans but also an obligation.

People drive hundreds of kilometres to attend the funeral of a neighbour they grew up next to while still in primary school. Black Africans will fly thousands of kilometres to attend a funeral of a mother's friend, which is how important the attendance of a funeral is in the black cultures. Molobi defines a funeral as 'the burial procession or place where all type of people meets when someone is dead'. Molobi (2006) submits that:

[F]uneral is an event that determines the popularity of the deceased and that of his/her family. This is often not deliberate but coincidental, and people will determine and judge the living standards of other people. If a huge number of people attend a funeral, people will often say that such a person was buried well or sent off well. (p. 11)
In African communities and culture, the 'send-off' given to the individual during the burial ceremony therefore involves the mourning of the entire community (Baloyi 2014:2).

In rural areas and towns, funerals are still attended by a large number of people even during COVID-19, because funerals are very important in such societies. In Africa, the events surrounding death are often described as the key cultural events of a particular area. Entire neighbourhoods and villages are drawn to them. Family members and friends who have migrated to other areas and countries are also known to travel back to attend funeral ceremonies. For Westerners, among whom death is normally a private and family affair, this is sometimes difficult to fathom.

\section{Funerals and burial rituals in the African context}

For most Africans, funerals involve a combination of both traditional and Christian elements. African funerals consist of two stages, pre-burial rituals and burial rituals. African scholars argue that death brings together the three dimensions of time: the past, the present, and the future. To affirm this, Masango (2006:935) submits that the notion of death creates a solution of continuity between the living and the dead. According to Mwakabana and Lutheran World Federation (2002:47), in African communities, burial is seen as a theatre where ancient rituals and ceremonies are enacted by the living to appease the dead, and this is to ensure the future.

Under the African cultural worldview, burial and mourning rituals are justified on several grounds including the need to pay due respect to the dead, protect the widows from attack of evil spirits, and to even encourage the living towards good deeds (Ewelukwa 2002:444).

Ademiluka (2009:9) noted that death in Africa, as in the Old Testament, is accorded the most important significance in midst of the other rites of passage. According to Mhaka (2014):

When a person dies, a ritual must be conducted to inform his consanguine of the death so that they will not encounter misfortunes. Death is believed to bring about mystical danger to the consanguine of the deceased. The ritual of informing the relative is meant to protect the consanguine of the decease. All relatives are usually informed about the death either by word of mouth or by some ritual act. (p. 9)

In this context, Africans communicate with their ancestors. Sacred communication enables ancestors to remain in contact with descendants for quite some time.

As part of the pre-burial rituals in many African communities, the body of the deceased is brought home for the final viewing by the family and the members of the communities. It is also a way for the deceased to spend their last night in their home before they embark on to another life in the land of the ancestors. Some families perform rituals praying to the ancestors to welcome the new ancestors in their fold. Some perform rituals to get the spirit of the dead person to leave the house. Some African communities also use this period as 
an opportunity to place the deceased favourite items such as clothes, favourite plate or spoon in the coffin. Because of these beliefs, it is important for Africans that the deceased are brought home the day before the funeral. If it is not done, it is believed that the spirit of the dead will not rest in peace and will return to the house and cause misfortune for the family.

The last stage of the burial rituals is performed at the burial site. It usually precedes by prayer to the ancestors to accept the dead and ends with the practice of throwing soil onto the grave by hand (Mbiti 1999:128).

\section{Importance of burial rites in the African context}

According to Kgatla (2014:87), the following are the primary effects of the rituals of death:

- Rituals of death have a transformation character and the function to integrate beliefs.

- Such rituals simplify complex and anomalous conditions into a simplified and straight forward habituation.

- These rituals stabilise the situation during the period of stress.

- These rituals protect the norms and ideals of a society at a time that is trying and difficult for all concerned.

- The rituals facilitate and enable the management of emotions during a time of transition.

- Rituals offer an explanation of the persistence of religious traditions in the face of the destructive forces and distortion due to the outside influences.

There are number of rituals that follows after death; reasons behind some of them remain unknown (Mwandayi 2011):

From a liturgical perspective, integration hereby means that the culture will influence the way prayer formularies are compassed and proclaimed, ritual actions are performed, and message proclaimed in art forms. (p. 78)

Rituals for the Africans and the African culture is a very sensitive issue, as it is a part of who they are, and a part of their pride as Africans. For one to come and say to African people this is wrong, this is right, is not so simple. One might have facts but what is important is to ensure that any such message/s is put across without offending someone's cultural beliefs and practices.

\section{An African liturgical and missional challenge}

The church is called to pastoral care for persons in need (Kelcourse 2002:137). This care is the church's response to the personal, social and spiritual needs of persons in the context and through the agency of the local community (Pillay 2017:10). Practically, the missional praxis of pastoral care requires that one understands and interprets human needs through theological and hermeneutical analysis (Steyn \& Masango 2011:2). The approaches for the theological and hermeneutical analysis were summarised in the following steps by Swinton and Mowat (2016:9):
1. Reflect on current praxis around a practice or situation that require critical attention.

2. Analyse and enter dialogue with other source of knowledge to discover what is actually going on.

3. Provide theological reflection that weighs God's intentions against the significances of what was discovered in stages 1 and 2 .

Various cultures have their own perspectives of mourning the loved ones and the church needs to be pragmatic as also empathetic towards its people during this time of the pandemic. According to Wepener (2014:3) 'Liturgy is a practically developed celebration/doksa of the congregation which finds expression in worship and celebration so that the gospel can be effectively communicated'. In light of this, when believers are bereaved, the church and the Pastoral body are not only concerned about the dead, but also see it as opportunity to both console the bereaved family and to preach salvation to sympathisers at the burial service. The consolation of the bereaved family, the funeral liturgy and the preaching of the word of God, become part of the missional assignment of the church in this context.

In South African rural areas, the whole village is considered to be one big family. Ubuntu in the African context is not limited to a definition by scholars or philosophers. It is their way of life. When there is a celebration, for example, a wedding, the whole village attends the wedding and joins in the celebration. Villages consider attendance by 'invitation only' to be taboo and many take offence to it, as it is believed that they are all family. When one family is mourning, the whole village mourns with the family. Hence, the attendance at a funeral in rural areas and some townships is always large. COVID-19 led funeral restrictions put a limit on the number of people allowed to attend a funeral. This however, remains a challenge in many African communities, as people still attend funerals and in large numbers despite funerals been identified as one of the wild spreaders of the virus. COVID-19 has changed the way African funerals are held and for many it remains a huge challenge to adjust to this 'new' normal.

According to Molobi (2006:2) in rural Africa, society's communal network provides support and assistance to the family in the event of death. Molobi (2006) argues that:

[B] urial societies emerged as a response to the social and economic stress of migration and urbanization. Members of various burial societies come from different churches, and they unilaterally agree on the issue of mutual financial support. (p. 2)

It does not matter whether the deceased belonged to a different church. All members of the village from different churches come in large numbers to support the family, from the day of the burial to the day of the funeral. Attending daily services at the house to support the family all week long leading to the day of the burial. Some even take time off work to help the family with the preparation of the funeral, some help with cooking, some with cleaning, some help financially; 
they help however they can. According to Molobi (2006:9) 'burial societies are governed by the concept of botho or Unbuntu as it is known among the African communities in South Africa'. Daily services leading to the funeral have been an integral part of the African culture for years and as part of the healing process for the family.

\section{Baloyi (2014) argues that:}

[S]ome traditional African people particular in rural villages, find it strange if the burial grave is dug with machinery. They prefer that people should dig the grave as a way of showing compassion. (p. 4)

They see this as one of the ways of the community help and physically take part in the mourning process. The day after the funeral, a goat is slaughtered for those who helped dug the grave, together with some members of the family.

In Africa, death is regarded as a dreaded event and seen as the beginning of the communication between the visible and the invisible worlds. Some communities in Africa believe that the goal of the life is to become an ancestor after death and to join the ancestors in the invisible world. This is one of the major reason why Africans believe that every person who dies must be given a 'befitting' funeral, accompanied by a number of traditional and religious rites and ceremonies. If this is not done, it is generally believed that the dead person may become a wandering ghost and will continue to torment those still living, especially members of deceased family who ought to give the deceased a 'befitting' funeral. As part of giving a 'befitting' funeral as expected in Africa, funeral rites are usually incorporated as parts of the fundamental aspects of the funeral ceremonies and in most cases usually precede actual burial of the deceased. The nature and the complexity of the various funeral rites that are usually performed, vary with the communities where the deceased originated, their cultural heritage, religion of practice, and the background of the dead or position they held in the community.

African liturgy is challenged due to the restrictions as a result of COVID-19, because the above-mentioned rituals among others requires the community and family to be there from the day the death is unannounced until the day of the funeral.

One of the challenges faced by ordained ministers in African communities during COVID-19 restrictions is how to deal with community members who still insist on viewing the deceased's body the day before the funeral. Bathing and dressing up a deceased of a loved one and gathering before the burial are essential parts of grieving for many cultures in South Africa. It was also observed that some families insist the dead body should not be covered in plastic. However, health professionals argue that dead bodies, essentially of those who passed away due to COVID-19, should be wrapped in plastic for health purposes to avoid the spread of the disease.

In light of the African pneumatic worldview as discussed in the article, we recommend that the African theology must place human existence before faith, since first we are human beings, and then believers. In doing so, the African theology must focus on the importance of belief in the God that creates and sustains the African people. Many Africans live at a subsistence level, and therefore most of their actions are motivated by the will and desire to survive both physically and spiritually in the present, and then in eternity.

Furthermore, while providing spiritual and emotional support to the bereaved family and the affected communities, the ministers should make it a point to educate their congregations on the importance of obeying the COVID-19 safety protocols in these challenging times. As part of the pastoral responsibilities, sympathisers could also be encouraged to participate in the ceremony through available virtual platforms.

\section{Conclusion}

In the light of COVID-19 restrictions and related challenges on funerals and burial rites in African communities, it is required of churches and church leaders to keep providing their pastoral and missional responsibilities while observing COVID-19 protocols. Churches are also required to use their platforms for creating awareness around the reality of COVID-19 on one's health. Religious leaders can request a list of people to attend a funeral before the actual funeral. Church members and sympathisers should be encouraged to participate in the funeral rites on available virtual platforms. This would help churches to comply with government policies in the fight against the spread of the virus.

\section{Acknowledgements Competing interests}

The authors declare that they have no financial or personal relationships that may have inappropriately influenced them in writing this article.

\section{Authors' contributions}

Both authors contributed equally to the writing of this article.

\section{Ethical considerations}

This article followed all ethical standards for research without direct contact with human or animal subjects.

\section{Funding information}

This research received no specific grant from any funding agency in the public, commercial or not-for-profit sectors.

\section{Data availability}

Data for the study would be well-kept for the next five years for academic and verification purposes. 


\section{Disclaimer}

The views and opinions expressed in this article are those of the authors and do not necessarily reflect the official policy or position of any affiliated agency of the authors.

\section{References}

Ademiluka, S.O., 2009, 'The sociological functions of funeral mourning: Illustrations from the Old Testament and Africa', OTE 22(1), 9-20.

Baloyi, E.M., 2014, 'Critical reflections on polygamy in the African Christian context', Missionalia 41(2), 164. https://doi.org/10.7832/41-2-12

Bassis, M.S., Celles, R.J. \& Levine, A., 1991, Sociology: An introduction, McGraw-Hill, New York, NY.

Beyers, J., 2010, 'What is religion? An African understanding', HTS Teologiese Studies/ Theological Studies 66(1), a341. https://doi.org/10.4102/hts.v66i1.341

Edwards, S.D., Makunga, N.V., Thwala, J.D. \& Mbele, P.B., 2009, 'The role of the ancestors in healing', Indilanga: African Journal of Indigenous Knowledge System 8(1), 1-11. https://doi.org/10.4314/indilinga.v8i1.48234

Ewelukwa, U., 2002, 'Post-colonialism, gender, customary injustice: Widows in African societies', Human Rights Quarterly 24(2), 424-486. https://doi.org/10.1353/ hrq.2002.0021

Hammersley, M. \& Atkinson, P., 2007, Ethnography principles in practice, Taylor and Francis, Abingdon.

Kelcourse, F.B., 2002, 'Pastoral counselling in the life of the church', Encounter 63 (1/2), 137.

Kgatla, P.S.T., 2014, 'Rituals of death enhance belief and belonging: Analysis of selected elements of Northern Sotho death rituals', Online Journal of African Affairs 3(6), 81-86.

Kurewa, J.W.Z., 2000, Preaching and cultural identity: Proclaiming the gospel in Africa Abingdon Press, Nashville, TN.

Magesa, L., 1997, African religion: The moral traditions of abundant life, Orbis Books, Maryknoll, NY.

Masango, M.J.S., 2006, 'African spiritualty that shapes the concept of Ubuntu', Verbum et Ecclesia 28(3), a195. https://doi.org/10.4102/ve.v27i3.195
Mbiti, J.S., 1975, Introduction to African religion, Praeger, New York, NY.

Mbiti, J.S., 1991, Introduction to African religion, Heinemann, Johannesburg.

Mbiti, J.S., 1999, “'Hearts cannot be lent": In search of peace and reconciliation in African traditional society', The Peinceton Seminary Bulletin XX(1), 1-12.

McVeigh, M.J., 1974, God in Africa: Conceptions of God in African traditional religion and Christianity, C. Stark, Cape Cod, MA.

Mhaka, E., 2014, 'Rituals and taboos related to death as repositories of traditional African philosophical ideas: Evidence from the Karanga of Zimbabwe', Academic Research International 5(4), 371-385.

Mndende, N., 2005, 'Ancestors and healing in African religion: A South African religion', in I. Wulfhorst (ed.), Ancestors, spirits and healing in Africa and Asia: A challenge to the church, pp. 13-24, Lutheran World Federation, Geneva.

Molobi, V., 2006, 'The history and potential of burial societies in creating basic Christian communities in South Africa', Studia Historiae Ecclesiasticae XXXII(2), 153-170.

Mpedi, L.G., 2008, 'The role of religious values in expanding social protection: A South African perspective', Acta Theologica 28(1), 105-125. https://doi.org/10.4314/ actat.v28i1.48870

Mwakabana, H.A.O. \& Lutheran World Federation, 2002, Crises of life in African religion and Christianity, Lutheran World Federation, Geneva.

Mwandayi, C., 2011, 'Death and after-life rituals in the eyes of the Shona: Dialogue with Shona customs in the quest for authentic', in J. Kügler, L. Togarasei, M.R. Gunda \& E.S Onomo (eds.), Bible in Africa Studies, vol. 6, University of Bamberg Press, Bamberg.

Pillay, J., 2017, 'The church as a transformation and change agent', HTS Teologiese Studies/Theological Studies 73(3), 4352. https://doi.org/10.4102/ hts.v73i3.4352

Steyn, T.H. \& Masango, M.J., 2011, 'The theology and praxis of practical theology in the context of the faculty of theology', HTS Teologiese Studies/Theological Studies 67(2), a956. https://doi.org/10.4102/hts.v67i2.956

Swinton, J. \& Mowat, H., 2016, Practical theology and qualitative research, SCM Press, London.

Wepener, C., 2014, 'Liturgical inculturation or liberation? A qualitative exploration of major themes in liturgical reform in South Africa', HTS Teologiese Studies/ Theological Studies 7(1), a2644. https://doi.org/10.4102/hts.v70i1.2644

White, P. 2015, 'The concept of diseases and health care in African traditional religion in Ghana', HTS Teologiese Studies/Theological Studies 71(3), a2762, 7 pages. https://doi.org/10.4102/hts.v71i3.2762 